\title{
Reassessment of Anthropic Modifications on the Early Pleistocene Hominin Specimen Stw53 (Sterkfontein, South Africa)
}

\author{
Réévaluation des modifications anthropiques sur le fossile d'hominine du Pleistocène Inférieur \\ Stw53 (Sterkfontein, Afrique du Sud)
}

\author{
R. Hanon - S. Péan - S. Prat \\ Received: 3 May 2017; Accepted: 10 January 2018 \\ (C) Société d'Anthropologie de Paris et Lavoisier SAS 2018
}

\begin{abstract}
Linear marks were observed on the maxillary zygomatic process of the early Pleistocene hominin fossil Stw53 from the Sterkfontein cave site. The taxonomic allocation of this specimen is still under debate, as it has been attributed either to the genus Homo or Australopithecus. Two alternative hypotheses have been proposed regarding the taphonomic agent responsible for the linear marks observed on this specimen. These modifications were initially assigned to anthropic cutmarks inflicted by stone tools, thus representing the earliest cutmarks discovered on hominin remains. Conversely, these linear marks were interpreted by others as non-anthropic modifications. In order to better understand the origin of the linear marks, a new taphonomic appraisal of these modifications was conducted using a multivariate statistical approach complemented by butchery and trampling experiments on extant mammal bones. This new study of Stw53 linear marks does not provide evidence for anthropic activities but, rather, supports the unintentional origin hypothesis.
\end{abstract}

Keywords Taphonomy · Cutmarks · Trampling · Stw53 · Sterkfontein

Résumé Des traces linéaires ont été observées sur le processus zygomatique de l'os maxillaire de l'hominine fossile sud-africain Stw53 découvert dans le site de Sterkfontein. L'attribution taxinomique de ce spécimen fait l'objet de nombreux débats. Il est attribué, selon les auteurs, soit au genre Homo, soit au genre Australopithecus. Deux hypothèses alternatives ont été proposées concernant l'identification

\footnotetext{
R. Hanon $(\bowtie) \cdot S$. Péan

Muséum national d'Histoire naturelle, UMR 7194,

1, rue René Panhard, 75013 Paris, France

e-mail : raphael.1.hanon@gmail.com

S. Prat

CNRS, UMR 7194, 17, place du Trocadéro, 75116 Paris, France
}

de l'agent taphonomique responsable des marques linéaires de Stw53. La première les attribue à des traces de découpe produites par un artefact lithique. Elles pourraient alors représenter les plus anciennes marques de découpe retrouvées sur des restes d'hominine. À l'inverse, ces marques linéaires ont été interprétées comme des modifications non anthropiques. Afin de mieux comprendre l'origine des marques observées sur le fossile Stw53, une étude préliminaire a été menée en appliquant des expérimentations taphonomiques afin de produire des marques de découpe et des marques de piétinement sur des os de mammifères actuels complétées par une approche statistique multivariée. Cette nouvelle étude des marques linéaires de Stw53 remet en cause leur origine anthropique et soutient plutôt l'hypothèse d'une origine non intentionnelle.

Mots clés Taphonomie - Marques de découpe - Piétinement Stw53 - Sterkfontein

\section{Introduction}

Since the description of anthropic modifications on the middle Pleistocene Bodo cranium from Ethiopia [1], several taphonomic studies have focused on possible perimortem damage observed on hominin fossil remains [e.g. 2-11]. The early Pleistocene Stw53 hominin cranium specimen is one of them. Moreover, in late Pliocene and early Pleistocene African contexts, the anthropic origin of linear marks observed on vertebrate remains has been debated by many authors [12-19].

Stw 53 hominin cranium was discovered by Alan Hughes in 1976 in the dolomitic cave of Sterkfontein (South Africa). It comes from either calcified and decalcified breccia, stratigraphically derived from either Member 5 [20] or the hanging remnant of non-tool-bearing Member 4 (Stw53 Infill) [10,21]. According to different authors, an age between 2.6 and 
1.49 million years old is proposed for this specimen [21-23]. No stone tools have been found in association with Stw53 [21].

The taxonomic allocation of this specimen is under debate. At the time of its discovery, Stw53 was attributed to Homo aff. H. habilis [20]. More recently, an allocation to the genus Australopithecus has been suggested [21], based on cranial capacity, a braincase frontally narrow and restricted, a flattened nasal skeleton and large teeth. However, new analyses based on cladistic [24] and comparative approaches [25] confirm the previous allocation to the Homo genus and the species habilis. Following these studies, a new species, Homo gautengensis, was defined [26], with the Stw53 specimen as the holotype.

Linear marks were described on the maxillary zygomatic process of Stw53 and interpreted by Pickering and colleagues as "cutmarks inflicted by a stone tool such as a sharp flake edge" [6]. The interpretation of Stw53 linear marks was based on macro- and microscopic (i.e. stereo microscope and scanning electron microscope, SEM) observations of the morphology and orientation of the grooves, their anatomical location, as well as the lack of any other linear mark on the macromammalian assemblage associated with the hominin specimen [6]. The striae are located in the masseter muscle insertion area and have been attributed to a mandib- ular disarticulation [6]. Several hypotheses were raised to explain their presence, including "cannibalism, curation, mutilation, and/or funerary procedures" [6, p. 583].

This assumption has far-reaching implications in terms of early hominin behaviours, as it would represent the earliest bone modifications of anthropic origin observed on hominin fossil [6,27]. Except Sterkfontein with Stw53, only TD6 level (between 800 and $900 \mathrm{ka}$ ) of the Gran Dolina site, at Atapuerca (Spain), has yielded hominin remains bearing cutmarks for the early Pleistocene period [3-5,8].

Conversely, it was mentioned that the zygomatic bone of Stw53 was discovered together with sharp-edged blocks lying against it, which could produce linear marks under sedimentary pressure and therefore without the action of any anthropic agent [10]. This raises the question of the distinction between cutmarks on this bone inflicted intentionally (i.e. by another hominin) and 'produced naturally by a small chert block' [10].

Many authors already showed that marks resulting from non-anthropic processes (e.g. sedimentary pressure, sedimentary abrasion, trampling) can mimic cutmarks (equifinality) $[12-14,16,17,19,28-30]$. Some criteria are recurrent and efficient to distinguish anthropic and trampling modifications. Among these criteria (Table 1), we can cite the number of marks in the assemblage and/or in a specimen [15,29],

Table 1 Morphological criteria used in this study to describe taphonomical linear marks on bones / Critères morphologiques utilisés dans cette étude pour décrire les marques linéaires taphonomiques sur os

\begin{tabular}{|c|c|}
\hline Criteria & Variables \\
\hline \multicolumn{2}{|l|}{ 1. Number of specimens } \\
\hline 2. Bone type & $1=$ long; $2=$ short; $3=$ flat \\
\hline 3. Position of marks & $1=$ shaft $; 2=$ epiphyses $; 3=$ variable \\
\hline 4. Association with others marks & $\begin{array}{l}0=\text { absence } ; 1=\text { fracture } ; 2=\text { polished surface } ; 3=\text { scraped surface } ; 4=\text { abraded surface; } \\
5=\text { gnawed surface } ; 6=\text { digested surface } ; 7=\text { perforated surface } ; 8=\text { variable }\end{array}$ \\
\hline 5. Number of marks & $1=$ numerous $(\geq 5) ; 2=$ few $(<5)$ \\
\hline 6. Distribution of marks & $1=$ the whole bone surface; $2=$ grouped; $3=$ individual; $4=$ variable \\
\hline 7. Orientation of marks & $\begin{array}{l}1=\text { parallel to the bone axis; } 2=\text { perpendicular to the bone axis; } 3=\text { oblique to the bone axis; } \\
4=\text { variable }\end{array}$ \\
\hline 8. Length & $1=$ long $(>7 \mathrm{~mm}) ; 2=$ medium $(3-7 \mathrm{~mm}) ; 3=$ short $(\leq 3 \mathrm{~mm}) ; 4=$ variable \\
\hline 9. Width & $1=$ large $(\geq 1 \mathrm{~mm}) ; 2=$ small $(<1 \mathrm{~mm}) ; 3=$ variable \\
\hline 10. Depth & $1=$ large $; 2=$ medium; $3=$ small $; 4=$ variable \\
\hline 11. Mark trajectory & $1=$ sinuous $; 2=$ straight $; 3=$ curved $; 4=$ variable \\
\hline 12. Division of groove ends & $0=$ absence $; 1=$ presence \\
\hline 13. Mark cross-section & $\begin{array}{l}1=\mathrm{V} \text {-shaped; } 2=\text { dissymmetric } \mathrm{V} \text {-shaped; } 3=\text { wide } \mathrm{V} \text {-shape (with a flat bottom } \backslash \text {-); } \\
4=\mathrm{U} \text {-shaped; } 5=\text { variable }\end{array}$ \\
\hline 14. Shoulder effect & $0=$ absence $; 1=$ presence \\
\hline 15. Flaking effect & $0=$ absence $; 1=$ presence \\
\hline 16. Internal microstriations & $0=$ absence $; 1=$ presence \\
\hline 17. Location of microstriations & $1=$ on the mark walls; $2=$ on the mark bottom; $3=$ on both places \\
\hline 18. Shape of microstriations & $1=$ continuous $; 2=$ discontinuous $; 3=$ variable \\
\hline 19. Trajectory of microstriations & $1=$ sinuous $; 2=$ straight $; 3=$ variable \\
\hline
\end{tabular}


the random position and orientation of the mark $[15,28]$, the variation in the dimensions $[29,31,32]$, the shoulder effect [15], the cross-section shape of the marks and microstriations [30].

In this paper, we propose to further test these two hypotheses by (1) conducting a taphonomic study on the original fossil Stw53 cranium from South Africa and (2) developing butchery and trampling experiments on extant mammal bones in order to better clarify the origin of the marks observed on the Stw53 specimen. This paper is focused on the descriptions and interpretations of the modifications observed on the early Pleistocene Stw53 hominin. Thus, this article does not aim at describing hominin specimens bearing cutmarks such as the middle Pleistocene Bodo [1].

\section{Materials and methods}

We studied 21 specimens from a reference taphonomic collection, which is hosted at the Institut de paléontologie humaine (Institute of Human Palaeontology) and the Muséum national d'Histoire naturelle (National Museum of Natural History), nine experimental specimens and the original Stw53 hominin cranium (Table 2). Material from the taphonomic collection is composed of long (radius, ulna, metapodial), flat (mandible, scapula) and short (carpal, phalanx) bones from large mammals (reindeer (Rangifer taran$d u s$ ), ox (Bos Taurus) and medium sized species) and one reindeer antler. This sample bears anthropic $(N=15)$, carnivore $(N=4)$ and rodent $(N=2)$ linear marks. Experimentation was conducted on long, flat and short bones: pig (Sus domesticus) femur, rib and vertebra of ox and pig.

Two experiments were conducted. Firstly, the trampling experimental protocol consisted of placing dry bones (pig vertebra, rib and tibia) in three kilograms of (1) flour and (2) sand, containing 108 sharp-edged blocks (83g), in order to observe the impact of the flakes present inside a soft and abrasive matrix. Flakes using Oldowan techniques were obtained by Adrian Arroyo with raw material (chert) from the Sterkfontein Valley. Bones were exposed to trampling by one of the authors (R. Hanon) for two minutes following the protocol established by Domínguez-Rodrigo et al. [30], which was to place dry bones in different sediments and expose them to trampling for two minutes. Pickering et al. [6] assumed that the cheek bone is "an area that we argue was naturally protected, unlikely to acquire the types of random scratches imparted by animals trampling around the cave floor and pushing the bone across abrasive sediments." Based on this assumption, we decided to apply experiments on vertebra, which present the best example of naturally protected bone area. Furthermore, ribs were also used due to their flat morphology similar to cranial bones.
Secondly, the butchery experiment was also conducted by one of the authors (R. Hanon) by defleshing fresh bones with meat still on them, in order to produce cutmarks on the same types of anatomical elements as the trampled ones (pig vertebra, rib and tibia), with experimental Oldowan stone flakes made of the same chert from the Sterkfontein Valley.

Specimens were described using a list of 19 criteria following several existing ones available in the literature $[15,28$ 30,33] and personal observations (R. Hanon) (Table 2) in order to identify the taphonomic agent(s) responsible for the marks. All comparative specimens were observed under Motic SMZ-143 binoculars (10× to $40 \times)$ and photographed using a AD7013MTL Dino-Lite microscope. In addition to Dino-Lite microscope acquisitions on the original Stw53 specimen (S. Prat), silicone (CPresident light body) high resolution moulds were made by one of us (S. Prat). Four specimens from the reference taphonomic collection (IPH/ MNHN), four experimental pieces (two butchered and two trampled bones) and Stw53 moulds, were observed with an environmental scanning electron microscope (ESEM), Tescan Vega 2 LSU. These analyses were undertaken at the Electron Microscopy Technical Platform of the Collections Direction of the Muséum of Natural History in Paris. ESEM acquisition was conducted according to methods applied by White [1] on Bodo and Pickering et al. [6] on Stw53.

Furthermore, unlike the previous study on Stw53 [6], we compared Stw53 marks with our reference taphonomic collection and experimental material, and we applied statistical methods. Hierarchical cluster analyses [UPGMA (unweighted pair group method with arithmetic mean), single linkage and neighbour joining method] were performed using PAST (version 2.17) software. The UPGMA is an agglomerative clustering approach, based on grouping the most similar specimens together, but with three different algorithms, which permit the testing of the strength of the clusters between the three methods. Moreover, multiple correspondence analysis (MCA) was performed to cluster the marks according to their similarities using XLSTAT (version 2013) software. All analyses were applied to the same taphonomic database (Table 2 ).

\section{Results}

Using both Dino-Lite and SEM acquisitions on Sterkfontein specimen Stw53, we observed three groups of linear marks, as described by Pickering et al. [6] (Fig. 1A-B). All of them are located on the zygomatic process of the right maxilla, referred to as Stw53c.

The first set of linear marks observed on Stw53c is a group of striations composed of a main mark with a wide V-shaped cross-section (Fig. 1C), which is usually observed in trampling marks [15]. The main groove is less than $3 \mathrm{~mm}$ 
Table 2 Database of the studied bone specimens bearing taphonomical linear marks. Groups are indicated as follows: A = anthropic; $\mathrm{C}=$ carnivore; $\mathrm{R}=$ rodent; $\mathrm{T}=$ trampling / Base de données des pièces osseuses étudiées portant des marques linéaires taphonomiques. Les groupes sont enregistrés comme suit : $A=$ anthropique ; $C=$ carnivore $; R=$ rongeur $; T:$ piétinement

\begin{tabular}{|c|c|c|c|c|c|c|c|c|c|c|c|c|c|c|c|c|c|c|c|}
\hline ITERIA & 2 & 3 & 4 & 5 & 6 & 7 & 8 & 9 & 10 & 11 & 12 & 13 & 14 & 15 & 16 & 17 & 18 & 19 & GROUP \\
\hline TAPH - 12 & 1 & 2 & 0 & 2 & 3 & 3 & 2 & 2 & 1 & 2 & 0 & 5 & 1 & 1 & 1 & 3 & 1 & 2 & $\mathrm{~A}$ \\
\hline TAPH - 13 & 2 & 1 & 0 & 2 & 4 & 2 & 2 & 2 & 1 & 2 & 1 & 5 & 1 & 0 & 1 & 3 & 1 & 2 & $\mathrm{~A}$ \\
\hline TAPH - 15 & 2 & 0 & 0 & 2 & 3 & 2 & 1 & 2 & 1 & 2 & 0 & 5 & 1 & 0 & 1 & 3 & 1 & 2 & A \\
\hline TAPH - 10 & 1 & 2 & 0 & 1 & 2 & 4 & 4 & 1 & 1 & 2 & 0 & 2 & 1 & 0 & 1 & 1 & 1 & 2 & A \\
\hline TAPH - 11 & 1 & 2 & 0 & 2 & 3 & 3 & 4 & 2 & 1 & 2 & 1 & 2 & 1 & 0 & 1 & 1 & 1 & 2 & A \\
\hline ТАРН - 16 & 2 & 2 & 0 & 2 & 2 & 4 & 2 & 2 & 1 & 2 & 0 & 2 & 1 & 0 & 1 & 1 & 1 & 2 & A \\
\hline ТАРН - 17 & 2 & 1 & 0 & 2 & 3 & 2 & 2 & 1 & 1 & 2 & 0 & 3 & 0 & 0 & 1 & 2 & 2 & 1 & A \\
\hline ТАРН - 18 & 2 & 2 & 0 & 2 & 2 & 2 & 2 & 1 & 1 & 2 & 0 & 2 & 1 & 0 & 1 & 1 & 1 & 2 & A \\
\hline ТАРН - 19 & 3 & 0 & 0 & 1 & 2 & 0 & 1 & 2 & 2 & 4 & 0 & 5 & 1 & 1 & 0 & 0 & 0 & 0 & $\mathrm{~A}$ \\
\hline ТАРН - 23 & 3 & 1 & 0 & 1 & 2 & 3 & 1 & 2 & 2 & 4 & 0 & 3 & 1 & 1 & 1 & 2 & 1 & 2 & A \\
\hline TAPH - 24 & 3 & 1 & 0 & 2 & 2 & 3 & 1 & 2 & 2 & 4 & 0 & 5 & 1 & 1 & 0 & 0 & 0 & 0 & $\mathrm{~A}$ \\
\hline ТАРН - 25 & 3 & 1 & 3 & 2 & 3 & 3 & 1 & 2 & 2 & 2 & 1 & 2 & 1 & 1 & 1 & 1 & 1 & 2 & A \\
\hline ТАРН - 8 & 1 & 1 & 8 & 1 & 2 & 2 & 1 & 3 & 4 & 4 & 0 & 5 & 0 & 0 & 0 & 0 & 0 & 0 & A \\
\hline ТАРН - 9 & 1 & 1 & 1 & 1 & 2 & 2 & 1 & 3 & 4 & 4 & 0 & 5 & 0 & 0 & 0 & 0 & 0 & 0 & A \\
\hline $\begin{array}{l}\text { G.1919 - } 1 \text { LE } \\
\text { PLACARD }\end{array}$ & 1 & 3 & 8 & 2 & 3 & 4 & 2 & 3 & 1 & 1 & 0 & 5 & 0 & 0 & 1 & 2 & 2 & 1 & $\mathrm{C}$ \\
\hline CRITERIA & 2 & 3 & 4 & 5 & 6 & 7 & 8 & 9 & 10 & 11 & 12 & 13 & 14 & 15 & 16 & 17 & 18 & 19 & GROUP \\
\hline $\begin{array}{l}\text { G.1919 - } \\
1 \text { COLL. H. } \\
\text { BREUIL }\end{array}$ & 1 & 3 & 4 & 1 & 1 & 2 & 2 & 1 & 4 & 1 & 0 & 5 & 0 & 0 & 1 & 2 & 1 & 1 & $\mathrm{C}$ \\
\hline $\begin{array}{l}\text { G.1919 - } \\
1 \text { COLL. H. } \\
\text { BREUIL } \\
\text { PHOTO }^{\circ} 11\end{array}$ & 1 & 3 & 8 & 1 & 1 & 2 & 1 & 1 & 4 & 1 & 0 & 4 & 0 & 0 & 0 & 0 & 0 & 0 & $\mathrm{C}$ \\
\hline $\begin{array}{l}\text { MDA / RDG / } \\
61\end{array}$ & 1 & 1 & 4 & 1 & 1 & 1 & 1 & 2 & 2 & 1 & 0 & 3 & 1 & 0 & 1 & 2 & 1 & 1 & $\mathrm{C}$ \\
\hline $\begin{array}{l}\text { SCP-R, E. } \\
\text { 1930. 2, } \\
\text { CANGO CAVE }\end{array}$ & 3 & 3 & 0 & 1 & 1 & 2 & 1 & 1 & 2 & 1 & 0 & 3 & 0 & 0 & 0 & 0 & 0 & 0 & $\mathrm{R}$ \\
\hline BOIS-R & 1 & 3 & 1 & 1 & 2 & 2 & 1 & 1 & 1 & 1 & 0 & 3 & 0 & 0 & 0 & 0 & 0 & 0 & $\mathrm{R}$ \\
\hline EXPA-1 & 3 & 1 & 0 & 2 & 2 & 4 & 4 & 3 & 4 & 4 & 0 & 5 & 1 & 1 & 0 & 0 & 0 & 0 & A \\
\hline EXPA-2 & 2 & 2 & 0 & 1 & 2 & 3 & 1 & 2 & 4 & 4 & 0 & 2 & 1 & 0 & 1 & 1 & 1 & 1 & A \\
\hline EXPA-3 & 1 & 1 & 0 & 1 & 2 & 4 & 1 & 2 & 4 & 4 & 0 & 2 & 0 & 0 & 1 & 1 & 1 & 3 & A \\
\hline EXPC-1 & 1 & 1 & 0 & 2 & 4 & 4 & 4 & 2 & 3 & 4 & 0 & 5 & 1 & 0 & 0 & 0 & 0 & 0 & $\mathrm{~T}$ \\
\hline EXPC-2 & 2 & 1 & 0 & 2 & 4 & 3 & 4 & 2 & 3 & 1 & 0 & 5 & 0 & 0 & 1 & 1 & 2 & 1 & $\mathrm{~T}$ \\
\hline STW53 SET1 & 3 & 1 & 0 & 2 & 2 & 3 & 3 & 2 & 3 & 1 & 0 & 3 & 0 & 0 & 1 & 1 & 2 & 1 & Stw53 \\
\hline STW53 SET2 & 3 & 1 & 0 & 2 & 2 & 3 & 3 & 2 & 3 & 1 & 0 & 3 & 0 & 0 & 0 & 0 & 0 & 0 & Stw53 \\
\hline STW53 SET3 & 3 & 1 & 0 & 2 & 2 & 3 & 3 & 2 & 3 & 1 & 0 & 5 & 0 & 0 & 0 & 0 & 0 & 0 & Stw53 \\
\hline
\end{tabular}

long, less than $1 \mathrm{~mm}$ wide and shallow. A few ancillary shorter striae are present along the main mark. Those are sinuous and their cross-sections are relatively wide Vshaped. Sinuous and discontinuous microstriations are visible on mark walls.

The second set is composed of two overlapping narrower and longer striae than the first set (Fig. 1D). They are slightly more than $3 \mathrm{~mm}$ long, less than $1 \mathrm{~mm}$ wide and shallower than Set 1 . We clearly observed relatively wide V-shaped striae, which can have been produced by trampling [34], without internal microstriations. One stria has a sinuous trajectory while the other one has a curvy ending (named barb) which is rarely observed (6/251 marks) in trampling experimental marks [30].

The third set described by Pickering et al. [6] was difficult to finely observe (Fig. 1E), even with a Dino-Lite 
A


D
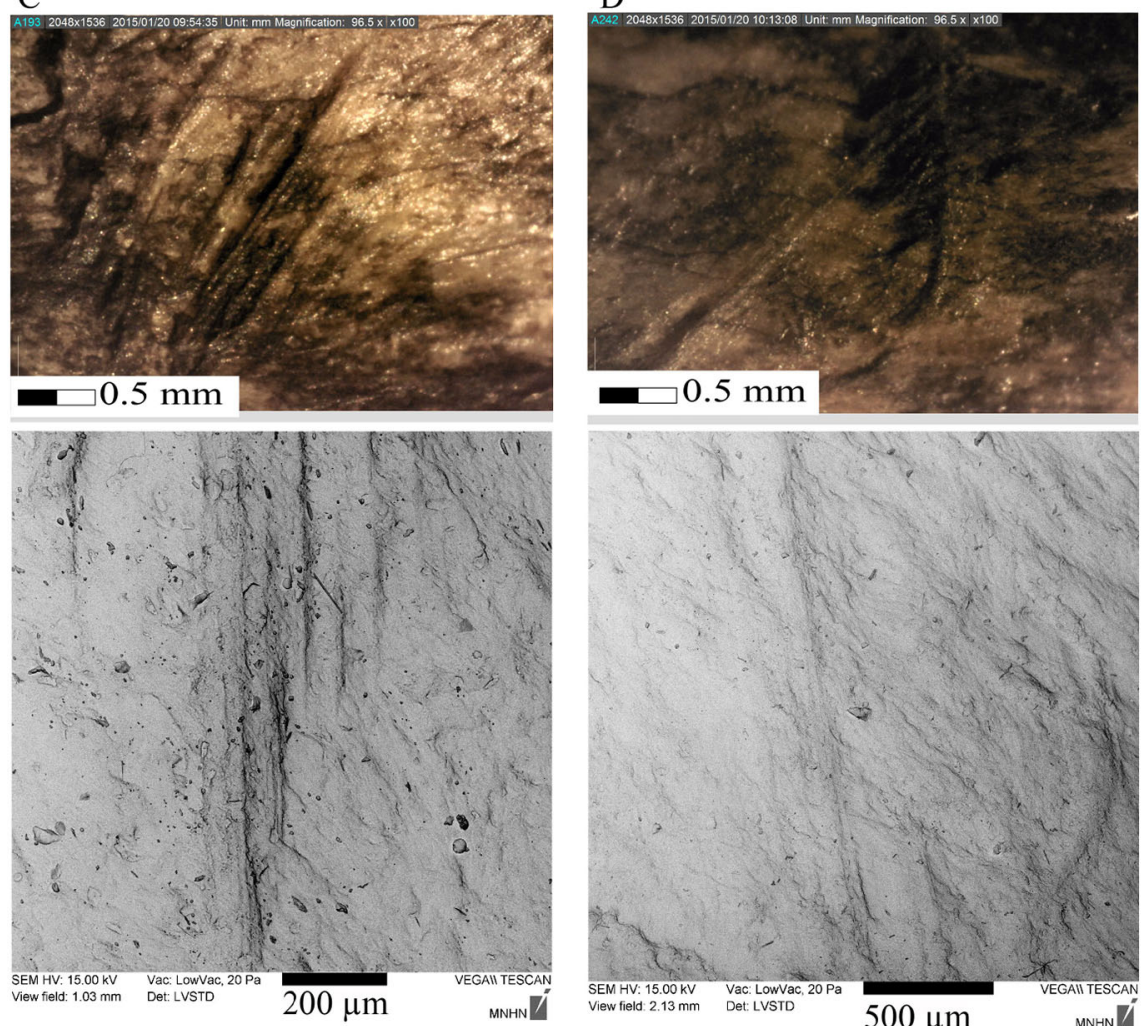

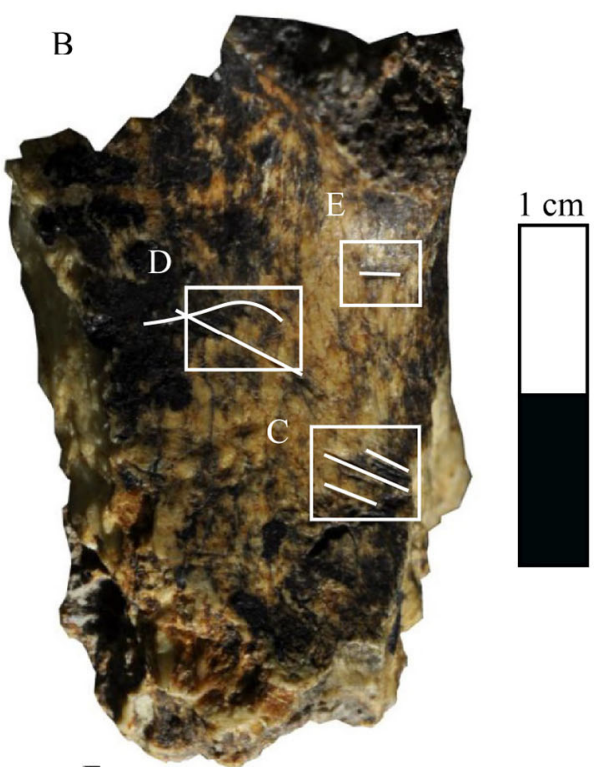

E
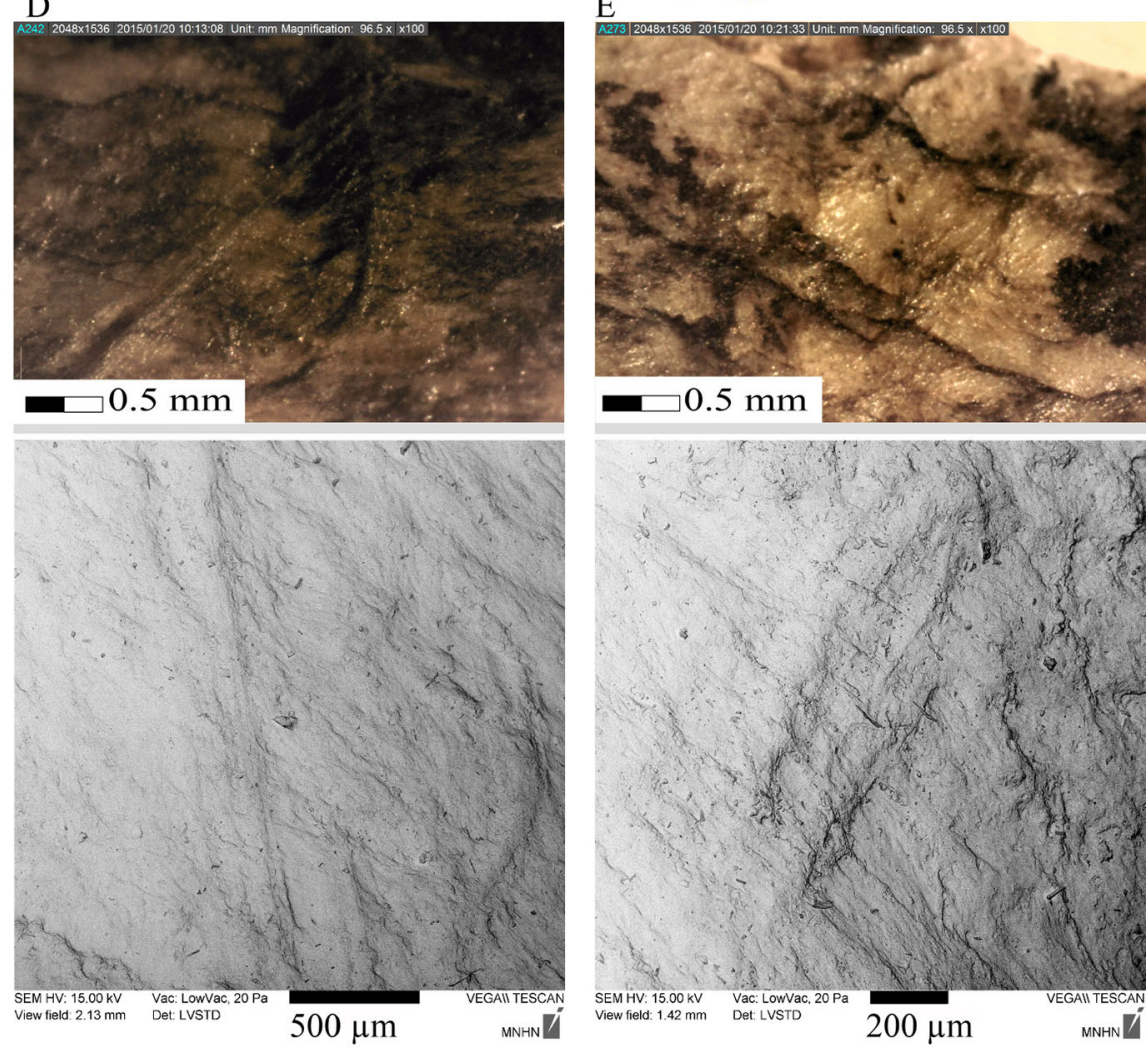

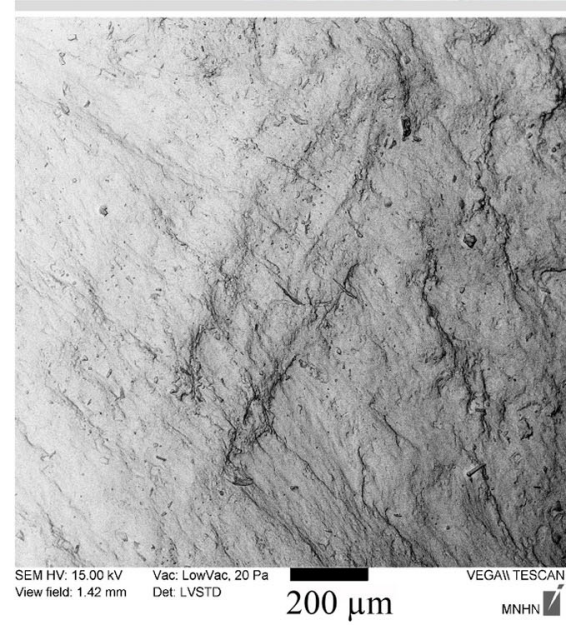

Fig. 1 A: Reconstitution of early Pleistocene hominin cranium Stw53 [15]. B: Stw53c maxillary zygomatic process and location of the 3 sets of linear marks (pictures taken by S. Prat). C: Set I under Dino-Lite and SEM; D: Set II; E: Set III / Une reconstitution du cranium Stw53, hominine du Pléistocène inférieur [15]. B : Processus zygomatique de l'os maxillaire Stw53c et la localisation des trois groupes de marques linéaires (photo S. Prat. C : Groupe I sous Dino-Lite et MEB ; D : Groupe II ; E : Groupe III)

microscope. Using the SEM, we observed three very short striae with a variable cross-section along their length, very irregular and without microstriation or shoulder effect. The marks are less than $3 \mathrm{~mm}$ long, less than $1 \mathrm{~mm}$ wide and shallow.
No stria was observed on the surface of the right temporal bone belonging to Stw53 specimen, despite microscopic investigation under Dino-Lite.

Experimental trampling in flour did not produce linear marks on bones, despite the presence of sharp-edged 


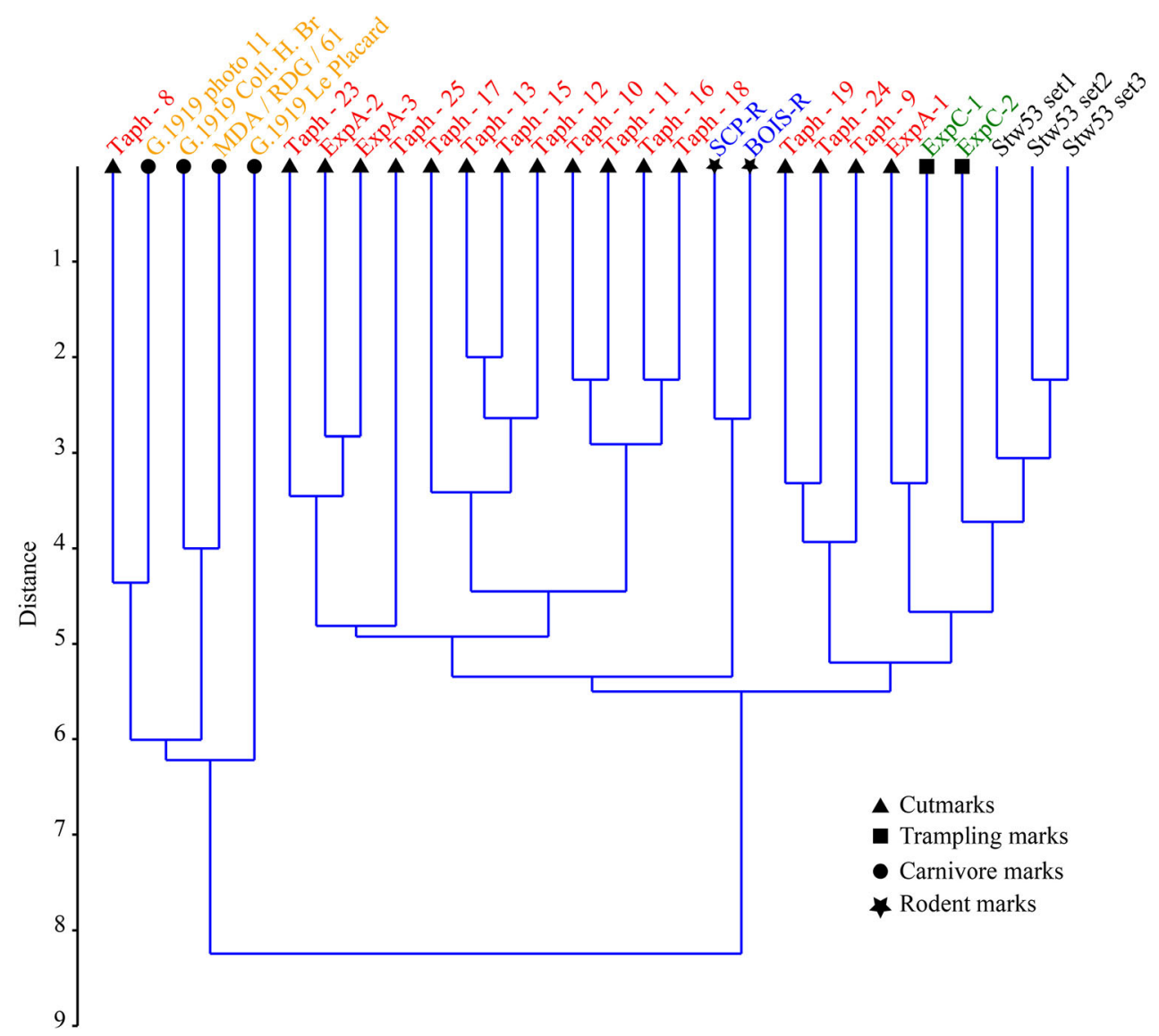

Fig. 2 UPGMA diagram of taphonomic linear marks observed on the Stw53c fossil and comparative bone sample / Diagramme UPGMA des marques linéaires taphonomiques observées sur le fossile Stw53c et dans l'échantillon de comparaison

blocks. Flour is probably too fine to bring a strong contact between sharp-edged blocks and bone surface. Concerning the experimental trampling in sand, we observed several of the typical morphological characteristics associated with trampling [mentioned by: $15,28,30$ ] such as a variation of the cross-section, the trajectory and the dimensions of linear marks, although they were produced during one experimental event.

During the butchery experiment, we produced several linear marks with many typical cutmark criteria such as dissymmetric V-shaped cross-section, shoulder effect, flaking and continuous microstriations on groove walls [30]. Trajectories of most striae are straight or oblique relatively to the bone axis.

Hierarchical clusters (Figs 2-4) permit the highlighting of the existence of groups of marks according to their taphonomic agents. We observed that carnivore and rodent marks are grouped together, except for the single linkage method which splits carnivores into two different groups (Fig. 3). There is an overlapping between all cutmarks and one trampling mark (ExpC-2), which could be explained by the presence of microstriations inside the groove, absent in the other trampling mark. Linear marks presented on the Stw53 specimen are linked to one trampling mark.

Four groups were distinguished by multiple correspondence analysis (MCA; Fig. 5). They correspond to the four taphonomic modifications: carnivore, rodent, butchery and trampling processes (Fig. 5). Stw53 marks are closer to trampling marks than to the majority of butchery ones. It seems that a combination of several criteria contributed to the axis $\mathrm{F} 1$ and $\mathrm{F} 2$. The main factors which contributed to the F1 axis are the straight trajectory of the groove (.06), the absence of internal microstriations (.06) and the position of the marks on the epiphyses (.04). On the contrary, the main contributing factors to the $\mathrm{F} 2$ axis are the variable position of the mark (.06), the presence of sinuous microstriation (.04) in the bottom of the groove (.05), the presence of flaking effect (.05) and the high width of the groove (.05).

The morphological variations (in terms of dimensions, trajectory and cross-section) of linear marks, cluster and MCA analyses are all in accordance, showing that Stw53 cranium marks are more similar to experimental trampling (using abrasive sediment and sharp-edged blocks) than to butchery marks. 


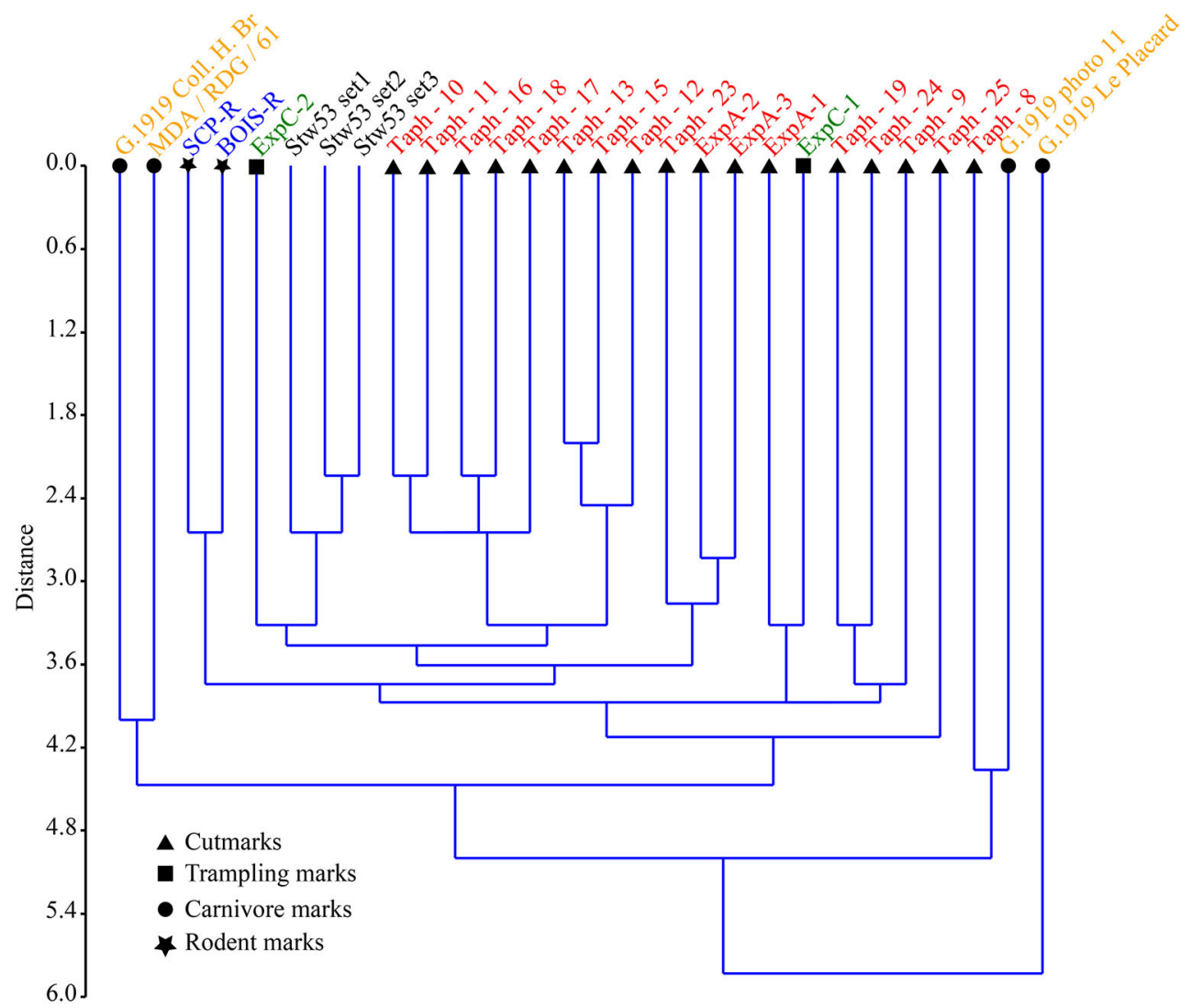

Fig. 3 Single linkage diagram of taphonomic linear marks observed on the Stw53c fossil and comparative bone sample / Diagramme single linkage des marques linéaires taphonomiques observées sur le fossile Stw53c et dans l'échantillon de comparaison

\section{Discussion and conclusion}

Linear marks are present on the right hominin maxillary zygomatic process (Stw53c) from Sterkfontein as three distinct sets of short striations. Two alternative hypotheses have been proposed to identify the taphonomic agent responsible for them: (1) anthropic [6] or (2) 'produced naturally by a small chert block' [10].

The unintentional abrasion of the bone against sharpedged blocks by trampling or under sedimentary pressure was rejected by Pickering et al. [6]. They based their argument on: (1) the lack of random striae caused by sedimentary abrasion on all 763 macromammalian fossils associated with Stw53, and on the more exposed surface of the Stw53 specimen; (2) 'the depths, nonrandom orientation, and discrete placements of these sets of striae (i.e. three sets, with different orientations)' [6, p.583]. Nevertheless, it was mentioned that, in the Stw53 breccia faunal assemblage, 'most fragmentation was incurred by geological forces such as sediment compaction and rock fall while the bones were lying on the cave talus slope' [35, p. 111]. This is consistent with Pickering's observations of linear marks on the masseteric fossa of Stw498 mandible [35], an Australopithecus prometheus from Member 4, morphologically similar to those on Stw53 [10], and considered to have been 'caused by dynamic contact with the jagged surface of a rock antiquity' and the author adds that 'there is no reason to believe that the marks were inflicted intentionally by stone tool' [35, p. 45]. As Stw 53c was discovered with sharp-edged blocks against it [10], these arguments are not strong enough to reject a non-anthropic origin for the linear marks on Stw53.

The longest mark on Stw53 specimen, which comprises a part of the Set 2, is $3 \mathrm{~mm}$ long, and the other marks are less than $3 \mathrm{~mm}$. Cutmarks are generally longer (more than $10 \mathrm{~mm}$ ) than trampling marks (less than $5 \mathrm{~mm}$ ) [36,37], except for sinew removal, which can produce shorter cutmarks [33]. Thus, the lengths of linear marks on Stw53c correspond rather to the trampling marks range than to the cutmarks one. However, recent experiments tend to show that the length is not a discriminant criterion for distinguishing cutmarks and trampling marks [38]. Stw53 marks depths are very variable and can correspond, in fact, to a trampling process as well $[15,28,29,31]$. The location of the marks on the zygomatic process of the maxilla was presented as evidence against the trampling hypothesis [6]. It would not be valid if the bone fragmentation had happened before the 




Fig. 4 Neighbour joining diagram of taphonomic linear marks observed on the Stw53c fossil and comparative bone sample / Diagramme Neighbour Joining des marques linéaires taphonomiques observées sur le fossile Stw53c et dans l'échantillon de comparaison



Fig. 5 MCA diagram of taphonomic linear marks on bones observed on the Stw53c fossil and comparative sample / Diagramme ACM des marques linéaires taphonomiques observées sur le fossile Stw53c et dans l'échantillon de comparaison 
mark occurrence. Furthermore, the calcified breccia context and decalcification process in South African sites, which could alter bone surface, require more careful taphonomic interpretations [39].

We support the hypothesis that a morphological variation of the linear marks (i.e. dimensions, trajectory, cross-section) in one assemblage and/or on one specimen is an accurate indicator of trampling processes [29,31,32]. Our study shows that the morphological variations of linear marks on Stw53c are consistent with a non-anthropic origin.

Moreover, because of the position of the marks on the masseter muscle insertion of the zygomatic maxillary process, we also attempted to observe marks on the temporal bone $[40,41]$. Thus, the lack of linear marks on the masseter muscle insertion of the temporal bone on the Stw53 specimen does not support the cutmarks hypothesis resulting from disarticulation or defleshing, which can produce similar marks $[42,43]$.

To conclude, based on statistically supported morphological comparisons of macro- and microscopic observations, our results allow us to interpret the linear marks present on the early Pleistocene hominin cranium Stw53 as trampling marks rather than cutmarks modifications. Based on these results, Stw53 would not exhibit the earliest unambiguous evidence of anthropic modifications on hominin remains.

Acknowledgments The authors would like to thank Professor Henry de Lumley (Institut de Paléontologie Humaine), Stéphanie Renault and Carole Vercoutère (Muséum national d'Histoire naturelle) for the authorization to study the comparative material, Bernhard Zipfel and the University of the Witwatersrand to study the Stw53 original specimen, Sylvain Pont and the Service de microscopie électronique à balayage de la direction des Collections of the Muséum national d'Histoire naturelle in Paris for the access to the scanning electron microscope and Adrian Arroyo (UCL) for producing the flakes and sharp-edge blocks. We thank the ANR ARCHOR (ANR-12-CULT-006) for support. We also thank Aurore Val and the second anonymous reviewer for their useful comments.

Conflict of interest: The authors do not have any conflict of interest to declare.

\section{References}

1. White TD (1986) Cut marks on the Bodo cranium: a case of prehistoric defleshing. Am J Phys Anthropol 69:503-9

2. White TD, Toth N (1989) Engis: preparation damage, not ancient cutmarks. Am J Phys Anthropol 78:361-7

3. Fernández-Jalvo Y, Díez C, Bermúdez de Castro JM, Carbonell E (1996) Evidence of early cannibalism. Science 271:277-8
4. Fernández-Jalvo Y, Díez C, Cáceres I, Rosell J (1999) Human cannibalism in the early Pleistocene of Europe (Gran Dolina, Sierra de Atapuerca, Burgos, Spain). J Hum Evol 37:591-622

5. Fernández-Jalvo Y, Andrews $\mathrm{P}$ (2001) Atapuerca, le conte de deux sites. L'Anthropologie 105:223-36

6. Pickering TR, White TD, Toth N (2000) Brief communication: Cutmarks on a Plio-Pleistocene hominid from Sterkfontein, South Africa. Am J Phys Anthropol 111:579-84

7. Le Mort F (2003) Modifications artificielles et restes humains préhistoriques : signification et interprétations. Revue archéologique de Picardie 21:117-23

8. Carbonell E, Cáceres I, Lozano M, Saladié P, et al (2010) Cultural cannibalism as a paleoeconomic system in the European lower Pleitocene. Curr Anthropol 51:539-49

9. Clarke RJ (2012) A brief review of history and results of 40 years of Sterkfontein excavations. In: Reynolds S, Gallagher A (eds) African genesis: perspectives on hominin evolution. Cambridge University Press, Cambridge, pp 120-43

10. Clarke RJ (2013) Australopithecus from Sterkfontein caves, South Africa. In: Reed KE, Fleagle JG, Leakey RE (eds) The paleobiology of Australopithecus. Springer, Dordrecht, pp 105-23

11. Bello SM, Wallduck R, Dimitrijević V, Živaljević I, et al (2016) Cannibalism versus funerary defleshing and disarticulation after a period of decay: comparisons of bone modifications from four prehistoric sites. Am J Phys Anthropol 161:722-43

12. Shipman P, Potts R (1981) Cutmarks made by stone tools on bones from Olduvai Gorge, Tanzania. Nature 291:577-80

13. Behrensmeyer AK, Gordon KD, Yanagi GT (1986) Trampling as a cause of bone surface damage and pseudo-cutmarks. Nature 319:768-71

14. Behrensmeyer AK, Gordon KD, Yanagi GT (1989) Nonhuman bone modification in Miocene fossils from Pakistan. In: Bonnichsen R, Sorg MH (eds) Bone modification. University of Maine Center for the Study of the First Americans, Orono, pp 99-120

15. Njau JK, Blumenschine RJ (2006) A diagnosis of crocodile feeding traces on larger mammal bone, with fossil examples from the Plio-Pleistocene Olduvai Basin, Tanzania. J Hum Evol 50:142-62

16. McPherron SP, Alemseged Z, Marean CW, et al (2010) Evidence for stone-tool-assisted consumption of animal tissues before 3.39 million years ago at Dikika, Ethiopia. Nature 466:857-60

17. Dominguez-Rodrigo M, Pickering TR, Bunn HT (2010) Configurational approach to identifying the earliest hominin butchers. PNAS 107:20929-34

18. Thompson JC, McPherron SP, Bobe R, et al (2015) Taphonomy of fossils from the hominin-bearing deposits at Dikika, Ethiopia. J Hum Evol 86:112-35

19. Sahle Y, El Zaatari S, White TD (2017) Hominid butchers and biting crocodiles in the African Plio-Pleistocene. PNAS, doi: 10.1073/pnas. 1716317114

20. Hughes A, Tobias P (1977) A fossil skull probably of the genus Homo from Sterkfontein, Transvaal. Nature 265:310-2

21. Kuman K, Clarke RJ (2000) Stratigraphy, artefact industries and hominid associations for Sterkfontein, Member 5. J Hum Evol 38:827-47

22. Schwarcz HP, Grün R, Tobias PV (1994) ESR dating studies of the australopithecine site of Sterkfontein, South Africa. J Hum Evol 26:175-81

23. Herries AIR, Shaw J (2011) Palaeomagnetic analysis of the Sterkfontein palaeocave deposits: implications for the age of the hominin fossils and stone tool industries. J Hum Evol 60:523-39

24. Prat S (2004) Les premiers représentants du genre Homo, en quête d'une identité. Apports de l'étude morphologique et de l'analyse cladistique. BMSAP 16:7-35 
25. Curnoe D, Tobias PV (2006) Description, new reconstruction, comparative anatomy, and classification of the Sterkfontein Stw53 cranium, with discussions about the taxonomy of other southern African early Homo remains. J Hum Evol 50:36-7

26. Curnoe D (2010) A review of early Homo in southern Africa focusing on cranial, mandibular and dental remains, with the description of a new species (Homo gautengensis sp. nov.). Homo 61:151-77

27. Pickering TR (2013) Rough and tumble: aggression, hunting, and human Evolution. University of California Press, Los Angeles, $208 \mathrm{p}$

28. Olsen S, Shipman P (1988) Surface modification on bone: Trampling versus butchery. J Archaeol Sci 15:535-53

29. Fischer JW (1995) Bone surface modifications in zooarchaeology. J Archaeol Method Theory 2:7-68

30. Domínguez-Rodrigo M, de Juana S, Galan AB, Rodríguez M (2009) A new protocol to differentiate trampling marks from butchery cut marks. J Archaeol Sci 36:2643-54

31. Andrews P, Cook J (1985) Natural modifications to bones in a temperate setting. Man 20:675-91

32. Patou-Mathis M (2002) Retouchoirs, compresseurs, percuteurs... Os à impressions et éraillures, Cahier X. Éditions Société préhistorique française, Paris, $136 \mathrm{p}$

33. Valensi P (1991) Étude des stries de boucherie sur les ossements de cerf élaphe des niveaux supérieurs de la grotte du Lazaret (Nice, Alpes-Maritimes). L'Anthropologie 95:797-830

34. Andrews P, Fernández-Jalvo Y (2012) How to approach perimortem injury and other modifications. In: Bell LS (ed) Forensic microscopy for skeletal tissues: Methods and protocols. Human Press, Totowa, NJ, 191-225

35. Pickering TR (1999) Taphonomic interpretations of the Sterkfontein early hominid site (Gauteng, South Africa) reconsidered in light of recent evidence. PhD dissertation, Department of Anthropology, University of Wisconsin, Madison, $557 \mathrm{p}$

36. Monnier GF, Bischoff E (2014) Size matters: An evaluation of descriptive and metric criteria for identifying cut marks made by unmodified rocks during butchery. J Archaeol Sci 50:305-17

37. Fernández-jalvo Y, Andrews P (2016) Atlas of taphonomic identifications. Springer Netherlands, $359 \mathrm{p}$

38. Orlikoff ER, Keevil TL, Pante MC (2017) A quantitative assessment of templing-induced modification to bone surfaces. Poster conference: Paleoanthropology Society

39. Val A, Stratford DJ (2015) The macrovertebrate fossil assemblage from the Name Chamber, Sterkfontein: taxonomy, taphonomy and implications for site formation processes. Palaeontol Afr 50:1-17

40. Villa P, Bouvill C, Courtin J, et al (1986) Cannibalism in the Neolithic. Science 233:431-7

41. Pérez VR (2012) The taphonomy of violence: recognizing variation in disarticulated skeletal assemblages. IJPP 2:156-65

42. Nilssen P (2000) An actualistic butchery study in South Africa and its implications for reconstructing hominid strategies of carcass acquisition and butchery in the Upper Pleistocene and PlioPleistocene. PhD Thesis, University of Cape Town $649 \mathrm{p}$

43. Soulier MC, Costamagno S (2017) Let the cutmarks speak! Experimental butchery to reconstruct carcass processing. J Arch Sci Reports 11:782-802 